ISSN: 2386-9658

\title{
Las palabras del Mal en la lengua y la literatura hispánicas. Textos reunidos y presentados por Marta Lacomba y Stéphane Oury
}

\author{
MARTA LACOMBA/STÉPHANE OURY \\ mlacomba07@gmail.com/stephane.oury@univ-lorraine.fr \\ Université Bordeaux Montaigne/ Université de Lorraine, France, EA 3943
}

Sería sin duda difícil concebir la literatura sin el mal... Y sin el bien por supuesto. Si partimos de la primera acepción de "mal" del diccionario de la Real Academia, nos encontramos con: "Lo contrario al bien, lo que se aparta de lo lícito y honesto". Es decir que el mal sería la ausencia o la negación del bien. Eso afirman desde luego las tres grandes religiones monoteístas, con el relato bíblico del árbol de la ciencia, de Adán y Eva desobedeciendo a Dios, dejándose tentar por el mal, por el pecado, con la consiguiente expulsión del Jardín del Edén. Expulsión que marca en realidad el principio de la Historia, de los andares por el mundo del hombre poseedor de libre albedrío, al que deberá aferrarse para establecer ese linde entre bien y mal. Podría decirse que marca también el principio de todas las historias, que necesitan si no ya un pecado original, al menos una caída o un tropezón. Así pues, el mal, o mejor dicho, la lucha contra el mal, en sus diversas modalidades, es un requisito para que haya alguna historia que narrar.

El mal reviste pues una pluralidad de formas y rostros, en función de las épocas y de los géneros abordados, y puede ser tanto algo exterior a los personajes, que lo sufren y/o intentan luchar contra él (como es el caso notablemente en la épica o en la literatura comprometida), como interior (el pecado, el sufrimiento y, ¿‘cómo no evocar el de “mal de amores”?). Cabe señalar además, que el mal puede ser no solo un poder destructor, sino también creador y baste un solo título, aunque ajeno a la literatura española para recordarlo, Les fleurs du Mal.

El propósito de los trabajos aquí presentados es analizar de qué manera el mal, los males, pueden ser dichos o bien disimulados, denunciados o invocados como material de creación. 